\title{
Identification of active sites for hydrogenation over Ru/SBA-15 using in situ Fourier-transform infrared spectroscopy
}

\author{
Hangjia Shen, Xianyuan Wu, Dahao Jiang, Xiaonian Li, Jun Ni* \\ Institute of Industrial Catalysis, Zhejiang University of Technology, Hangzhou 310014, Zhejiang, China
}

\section{A R T I C L E I N F}

\section{Article history:}

Received 25 November 2016

Accepted 30 December 2016

Published 5 September 2017

\section{Keywords:}

Ru/SBA-15 catalyst

In-situ Fourier-transform infrared

spectroscopy

Hydrogenation

Active site

Hydrogen spillover

\section{A B S T R A C T}

The active sites for hydrogenation over Ru/SBA-15 catalysts were identified using in situ Fourier-transform infrared spectroscopy. The amount of active sites was proportional to the interfacial circumference of the Ru particles. In contrast, the rate of hydrogen spillover from Ru to the support was inversely proportional to the size of the Ru metal particles. Consequently, a catalyst with small Ru metal particles has a high rate of hydrogen spillover but a low density of active sites, whereas one with large Ru particles has a low rate of hydrogen spillover but a high density of active sites. The formation of these active sites is probably an intermediate step in hydrogen spillover.

(C) 2016, Dalian Institute of Chemical Physics, Chinese Academy of Sciences. Published by Elsevier B.V. All rights reserved.

\section{Introduction}

The use of SBA-15-supported Ru catalysts in reactions such as hydrogenation $[1,2]$ and hydrogenolysis $[3,4]$ is becoming increasingly important because of the good performance of such catalysts in $\mathrm{H}_{2}$ activation. The surface area of SBA-15 is higher than those of previously reported supports for Ru catalysts [5,6], and it has an ordered mesoporous structure, which favors high dispersion of Ru. SBA-15 has few acidic or basic sites and did not affect the studied reactions. The high reactivity of Ru/SBA-15 is therefore normally attributed to high dispersion of small Ru particles [7]. However, strong binding of spillover hydrogen to $\mathrm{SiO}_{2}$ has been detected on $\mathrm{SiO}_{2}$-supported $\mathrm{Ru}$ catalysts [8]. Moreover, the addition of $\mathrm{Ru}$ as a promoter in $\mathrm{SiO}_{2}$-supported catalysts improves the reducibilities and activities of the catalysts; this is also ascribed to hydrogen spillover
[9]. These findings emphasize the importance of hydrogen spillover in reactions involving hydrogen, and raise the following issues in understanding of catalysts under working conditions. (1) Are the active sites for hydrogenation on $\mathrm{Ru} / \mathrm{SBA}-15$ catalysts Ru metal particles or the support? (2) How does hydrogen spill over from Ru to SBA-15? However, to the best of our knowledge, such a fundamental understanding of reaction mechanisms and the nature of active sites is still lacking.

In situ or in operando experimental methods need to be used to address these issues of real working catalysts [10]. In situ infrared (IR) spectroscopy is a powerful non-destructive technique, and is particularly used to probe surface sites and reaction mechanisms at the molecular level during catalytic reactions [11]. For example, IR spectroscopy has shown that benzene adsorption increases back-bonding of Pt $d$ electrons to CO antibonding orbitals, based on the shift in the $v(\mathrm{CO})$ vibration

\footnotetext{
* Corresponding author. Tel/Fax: +86-571-88320092; E-mail: Junni@zjut.edu.cn

This work was supported by the National Natural Science Foundation of China (21303163), the Natural Science Foundation of Zhejiang Province (LY13B030006, LY17B060006), the Qianjiang Talent Project in Zhejiang Province (QJD1302011), and the Scientific Research Fund of Zhejiang Provincial Education Department (Y201328681).
}

DOI: 10.1016/S1872-2067(16)62571-8 | http://www.sciencedirect.com/science/journal/18722067 | Chin. J. Catal., Vol. 38, No. 9, September 2017 
to lower frequencies. This indicates that benzene is adsorbed on a single Pt atom (as in $\pi$ arene complexes) with global transfer of electrons to Pt [12]. In situ IR spectroscopy has also shown that during the catalytic cycle in Baeyer-Villiger oxidation on Sn-zeolite beta, a ketone is coordinated to the Lewis acid center, resulting in carbonyl group activation [13].

Here, we report that the active sites for hydrogenation reactions over Ru/SAB-15 can be identified using in situ Fourier-transform IR (FTIR) spectroscopy. The formation of these active sites is probably the intermediate step in hydrogen spillover.

\section{Experimental}

\subsection{Catalyst preparation}

SBA-15 was synthesized using a previously reported method [14]. P123 (2 g) was completely dissolved in $1.6 \mathrm{~mol} / \mathrm{L} \mathrm{HCl}$ $(75 \mathrm{~mL})$, and tetramethyl orthosilicate $(3.3 \mathrm{~g})$ was added under vigorous stirring; stirring was continued for about $20 \mathrm{~h}$. The temperature was kept at $40{ }^{\circ} \mathrm{C}$. The resultant white mixture was transferred to a Teflon-lined autoclave and aged at $100{ }^{\circ} \mathrm{C}$ for $24 \mathrm{~h}$ without stirring. The white powder was recovered, washed, and dried at $110^{\circ} \mathrm{C}$ for $6 \mathrm{~h}$. Calcination at $550{ }^{\circ} \mathrm{C}$ for 10 $\mathrm{h}$ in air gave mesoporous SBA- 15 .

Supported Ru catalysts with specific Ru loadings were prepared using a two-solvents method $[15,16]$. Typically, an aqueous solution of $\mathrm{RuCl}_{3}(3.0 \mathrm{~mL})$ was added gradually to cyclohexane $(25.0 \mathrm{~mL})$ containing a support material (SBA-15 or $\mathrm{Al}_{2} \mathrm{O}_{3}, 1.0 \mathrm{~g}$ ) at $25^{\circ} \mathrm{C}$. After vigorous stirring for $15 \mathrm{~min}$, the dark-brown solution became colorless and the originally white support became black. The black powder was separated by centrifugation and dried at $100{ }^{\circ} \mathrm{C}$ for $6 \mathrm{~h}$; the product is denoted by $\mathrm{Ru} /$ support (wt\%). Pd/SBA-15 (4\%) was prepared by impregnation with $\mathrm{PdCl}_{2}$.

\subsection{Catalyst characterization}

In situ FTIR spectroscopy was performed using a Thermo Nicolet NEXUS 6700 spectrometer equipped with a mercury cadmium telluride (MCT) detector. A custom-made IR cell enabled spectra to be recorded at ambient temperature and at catalyst activation temperatures (up to $500{ }^{\circ} \mathrm{C}$ ). Self-supporting disks $(9.0 \mathrm{mg}$ ) were prepared for IR studies and physisorbed molecules were removed using a He flow. FTIR spectra were collected with 32 scans at a resolution of $4 \mathrm{~cm}^{-1}$ at different time intervals until a steady state was reached. The catalyst was reduced in situ with $\mathrm{H}_{2}$ at $400{ }^{\circ} \mathrm{C}$ for $30 \mathrm{~min}$ at a ramping rate of $20^{\circ} \mathrm{C} / \mathrm{min}$, swept with $\mathrm{He}$ for $30 \mathrm{~min}$, and cooled to 110 ${ }^{\circ} \mathrm{C}$ under He. These spectra were used as background for obtaining differential FTIR spectra.

The catalyst was subsequently treated using the following procedures; the gas flow rate was kept at $30 \mathrm{~mL} / \mathrm{min}$, unless otherwise stated. (a) $\mathrm{H}_{2}$ adsorption. The sample was treated in a $\mathrm{H}_{2}$ flow at $110{ }^{\circ} \mathrm{C}$ until a stable FTIR spectrum was obtained. Blank SBA-15 was treated in the same way for comparison. (b) H-D exchange. After procedure (a), the gas was switched to $D_{2}$ to achieve H-D exchange. Spectra were collected until no change in the $\mathrm{OH}$ vibration peak was detected. The sample was then swept with He to expel $\mathrm{D}_{2}$ until a clean spectrum was obtained. The sample was then retreated with $\mathrm{D}_{2}$ and IR spectra of the sample without any interference from $\mathrm{H}_{2}$ were obtained. (c) $\mathrm{CO}$ adsorption. After the catalyst had been activated and cooled to $110{ }^{\circ} \mathrm{C}$ under $\mathrm{He}$, $\mathrm{CO}$ was pulsed into the He stream three times using a six-way valve. After each pulse, the sample was swept with He for more than $10 \mathrm{~min}$ and spectra were recorded. After three pulses, the sample was swept with He for more than $8 \mathrm{~h}$.

Transmission electron microscopy (TEM) was performed using a Tecnai G2 F30 S-Twin instrument (Philips-FEI Company) operated at $300 \mathrm{kV}$. After $\mathrm{H}_{2}$ adsorption, the samples were dispersed in ethanol and then supported on a $\mathrm{Cu}$ grid for TEM measurements.

\section{Results and discussion}

The in situ FTIR spectra in the range $2250-1850 \mathrm{~cm}^{-1}$ of the reduced samples after adsorption of $\mathrm{H}_{2}$ at $110{ }^{\circ} \mathrm{C}$ are shown in Fig. 1. No vibration bands from Pd/SBA-15 (4\%), $\mathrm{Ru} / \mathrm{Al}_{2} \mathrm{O}_{3}$ (4\%), and SBA-15 were detected in this range, but a peak at $1996 \mathrm{~cm}^{-1}$ was observed for $\mathrm{Ru} / \mathrm{SBA}-15$ (4\%). These results imply that formation of this band is associated with the presence of both $\mathrm{Ru}$ and SBA-15, but is not related to the $\mathrm{Ru}-\mathrm{H}$ bonds in $\mathrm{Ru}$ metallic clusters, which would be detected for $\mathrm{Ru} / \mathrm{Al}_{2} \mathrm{O}_{3}$. It has been reported that $\mathrm{Ru}-\mathrm{H}$ species cannot be observed using IR, although adsorbed hydrogen species on various supported metals, e.g., $\mathrm{Pt} / \mathrm{Al}_{2} \mathrm{O}_{3}, \mathrm{Ir} / \mathrm{Al}_{2} \mathrm{O}_{3}, \mathrm{Ni} / \mathrm{Al}_{2} \mathrm{O}_{3}$, $\mathrm{Rh} / \mathrm{Al}_{2} \mathrm{O}_{3}$, and $\mathrm{Ni} / \mathrm{SiO}_{2}$ have been observed $[17,18]$. In addition, the intensity of the band arising from the combination tone vibration [19] of $\mathrm{Si}-0$ on $\mathrm{Ru} / \mathrm{SBA}-15$ at $1866 \mathrm{~cm}^{-1}$ did not change after exposure to $\mathrm{H}_{2}$, thus the intensity of the Si-O overtone band at $1985 \mathrm{~cm}^{-1}$ was constant. The possibility that the band at $1996 \mathrm{~cm}^{-1}$ can be ascribed to the $\mathrm{Si}-0$ overtone can therefore be ruled out.

$\mathrm{CO}$ was adsorbed on $\mathrm{Ru} / \mathrm{SBA}-15$ (4\%) to enable the band at $1996 \mathrm{~cm}^{-1}$ to be distinguished from those for adsorbed CO species. Fig. 2(a) shows that at low coverage of the Ru surface with

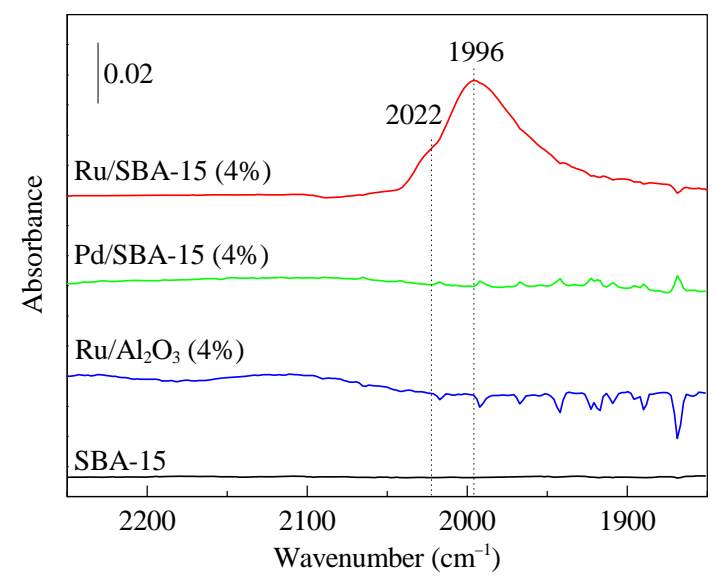

Fig. 1. Differential FTIR spectra of catalysts exposed to $\mathrm{H}_{2}$ flow for 30 $\min$ at $110^{\circ} \mathrm{C}$. 

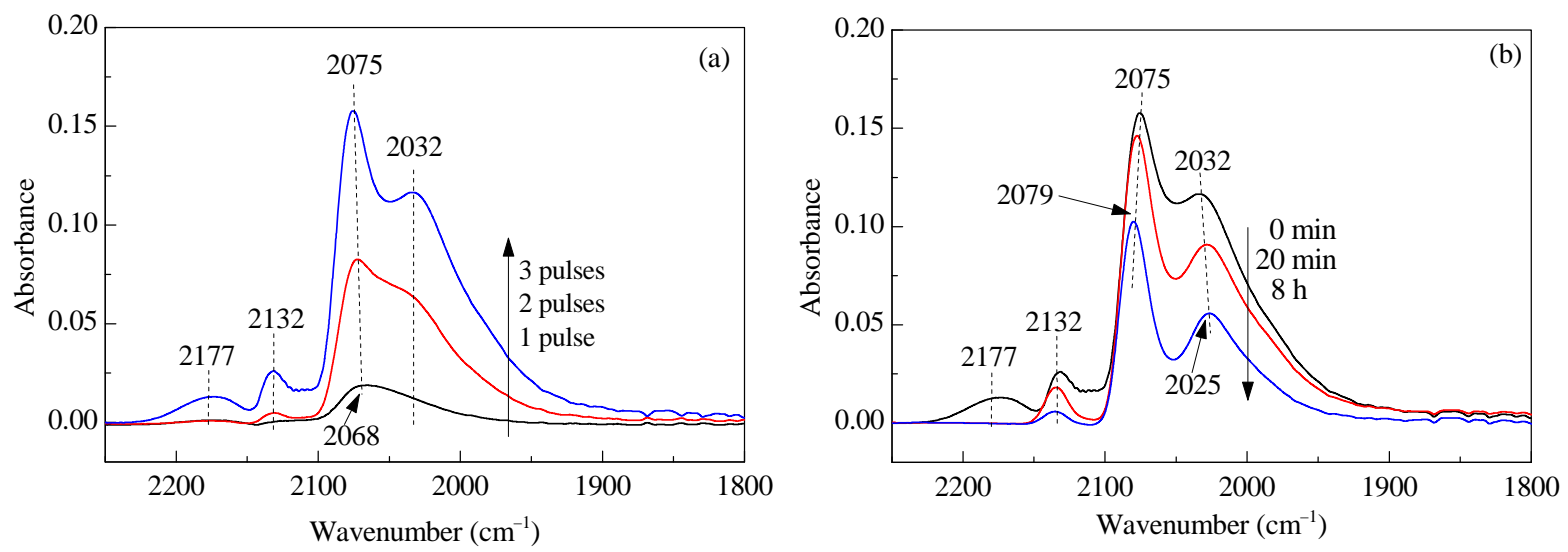

Fig. 2. In situ FTIR spectra of $\mathrm{CO}$ adsorbed on reduced Ru/SBA-15 (4\%) as a function of increasing CO coverage (a) and swept with a He flow at various times (b) at $110^{\circ} \mathrm{C}$. CO was introduced using a six-way valve (about $2 \mu \mathrm{L}$ ) with $\mathrm{He}$ as the carrier gas.

CO, a band at $2068 \mathrm{~cm}^{-1}$ ascribed to CO linearly adsorbed on $\mathrm{Ru}^{\delta+}$ appeared [20]. This band developed together with a band at $2132 \mathrm{~cm}^{-1}$, both related to $\mathrm{Ru}^{n+}(\mathrm{CO})_{x}$ multi-carbonyls [21], as coverage with $\mathrm{CO}$ increased until a band at $2177 \mathrm{~cm}^{-1}$ indicating physisorbed $\mathrm{CO}$ appeared. Few of these chemisorbed $\mathrm{CO}$ molecules were removed when the system was flushed with He at $110{ }^{\circ} \mathrm{C}$, even after $8 \mathrm{~h}$ (Fig. 2(b)). In addition, the intensity of the carbonyl band at $2068 \mathrm{~cm}^{-1}$ created by the first CO pulse (Fig. 2(a)) was lower than that of the band at $1996 \mathrm{~cm}^{-1}$ shown in Fig. 1. The wavenumber difference is therefore not caused by a surface coverage effect because carbonyl bands with wavenumbers higher than $2068 \mathrm{~cm}^{-1}$ are expected to appear with increasing $\mathrm{CO}$ coverage. The $\mathrm{CO}$ pulse adsorption results prove that the band at $1996 \mathrm{~cm}^{-1}$ does not arise from any carbonyl species formed on $\mathrm{Ru}$.

Formation of the band at $1996 \mathrm{~cm}^{-1}$ was reversible in the case of Ru/SBA-15 (4\%). The band developed gradually when the catalyst was exposed to $\mathrm{H}_{2}$ and reached its maximum intensity after $60 \mathrm{~min}$ (Fig. 3(a)). Subsequent flushing with He led to the disappearance of this band, as shown in Fig. 3(b). This band therefore cannot be assigned to spillover hydrogen on SBA-15 because the migration of hydrogen from $\mathrm{Ru}$ to $\mathrm{SiO}_{2}$ is irreversible [8]. The slow growth of this band during exposure for $1 \mathrm{~h}$ also indicates that it cannot be attributed to hydrogen chemi- sorbed on $\mathrm{Ru}$ because hydrogen saturates the Ru particle surfaces in a shorter time (less than a few minutes) [8].

Based on the above discussion, we conclude that the band at $1996 \mathrm{~cm}^{-1}$ cannot be ascribed to adsorbed $\mathrm{H}$ species on either Ru metal particles or the SBA-15 support. We postulate that the adsorbed $\mathrm{H}$ species are located at the interface between the $\mathrm{Ru}$ metal particles and the support. To confirm this hypothesis, we performed experiments using $\mathrm{Ru}$ with various interfacial circumferences on SBA-15 by tuning the Ru metal particle size. If the amount of $\mathrm{H}$ species is proportional to the interfacial circumference of $\mathrm{Ru}$, these species reside along the $\mathrm{Ru}-\mathrm{SiO}_{2}$ interface on the periphery of the exposed Ru particles. Fig. 4 shows TEM images of Ru/SBA-15 catalysts with various $\mathrm{Ru}$ contents. The mean Ru particle sizes calculated from 100 to $150 \mathrm{Ru}$ particles in these TEM images are listed in Table 1. Based on a spherical model (equations (1) and (2)), the Ru particle circumferences were calculated using equation (3); they are presented in Table 1.

$$
\begin{gathered}
N \cdot \frac{4}{3} \pi r^{3} \cdot \rho=m_{\text {cat }} \cdot \omega \\
N \cdot 2 \pi r=C \\
C=3 m_{\text {cat }} \cdot \omega /\left(2 r^{2} \cdot \rho\right)
\end{gathered}
$$

where $\rho$ is the density of $\mathrm{Ru}\left(12.37 \mathrm{~g} / \mathrm{cm}^{3}\right), N$ is the number of $\mathrm{Ru}$ particles, $r$ is the Ru particle radius, $\omega$ is the Ru loading, and
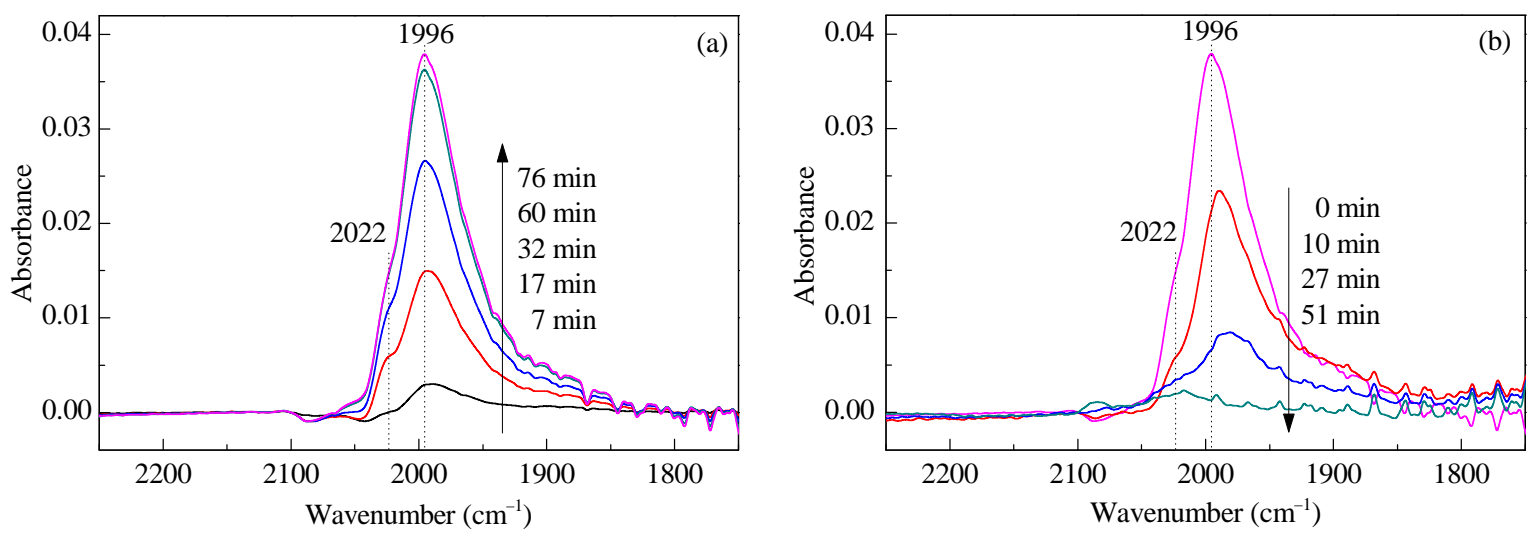

Fig. 3. Evolution of in situ FTIR spectra of reduced Ru/SBA-15 (4\%) in $\mathrm{H}_{2}$ at $110{ }^{\circ} \mathrm{C}$. (a) During exposure to $\mathrm{H}_{2}$ after reduction; (b) During flushing with $\mathrm{He}$ after exposure to $\mathrm{H}_{2}$. 

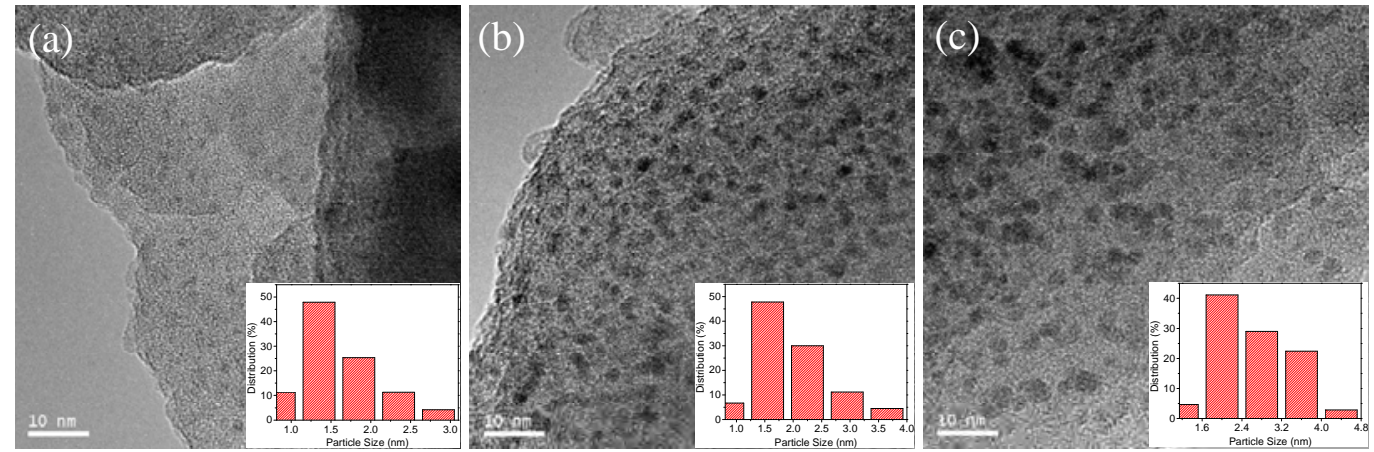

Fig. 4. TEM images and size distributions of Ru particles of (a) Ru/SBA-15 (1\%), (b) Ru/SBA-15 (4\%), and (c) Ru/SBA-15 (10\%).

Table 1

Textural properties of catalysts.

\begin{tabular}{lccc}
\hline Catalyst & $D_{\mathrm{Ru}}(\mathrm{nm})$ & $C_{\mathrm{Ru}}\left(10^{7} \mathrm{~m}\right)$ & $S$ \\
\hline $\mathrm{Ru} / \mathrm{SBA}-15(1 \%)$ & 1.6 & 1.7 & 0.578 \\
$\mathrm{Ru} / \mathrm{SBA}-15(4 \%)$ & 1.8 & 5.4 & 3.01 \\
$\mathrm{Ru} / \mathrm{SBA}-15(10 \%)$ & 2.6 & 6.5 & 3.83 \\
\hline
\end{tabular}

$D_{\mathrm{Ru}}$ : Ru particle size; $C_{\mathrm{Ru}}$ : Total circumference of Ru particles; $S$ : Band area in the range of $2100-1800 \mathrm{~cm}^{-1}$ at saturation in $\mathrm{H}_{2}$.

$C$ is the total circumference of the Ru particles.

Fig. 5 shows the evolution of the in situ FTIR spectra of reduced $\mathrm{Ru} / \mathrm{SBA}-15$ with various $\mathrm{Ru}$ loadings at $110{ }^{\circ} \mathrm{C}$. The IR spectra of Ru/SBA-15 (4\%) are shown in Fig. 3(a). The band areas at surface saturation with $\mathrm{H}_{2}$ were calculated to be 0.578 , 3.01, and 3.83 for Ru/SBA-15 (1\%), Ru/SBA-15 (4\%), and $\mathrm{Ru} / \mathrm{SBA}-15$ (10\%), respectively (Table 1). It can be seen from Table 1 that the band area at saturation increased linearly with increasing $\mathrm{Ru}$ particle circumference, indicating that the species corresponding to the bands in the range $2100-1800 \mathrm{~cm}^{-1}$ reside at the interfacial sites between $\mathrm{Ru}$ particles and the support. For the sake of convenience, we denote these sites by $\mathrm{S}_{\mathrm{x}}$. A precondition of the formation of special species is the presence of both $\mathrm{Ru}$ metal and $\mathrm{SiO}_{2}$ in the hydrogen atmosphere, therefore the process can be represented by the proposed model shown in Scheme 1. Molecular $\mathrm{H}_{2}$ dissociates on active Ru metal sites and saturates the Ru surface within a few minutes. The dissociated hydrogen atoms then migrate from the $\mathrm{Ru}$ metal sites to the $\mathrm{S}_{\mathrm{x}}$ sites between $\mathrm{Ru}$ and $\mathrm{SiO}_{2}$; this pro-

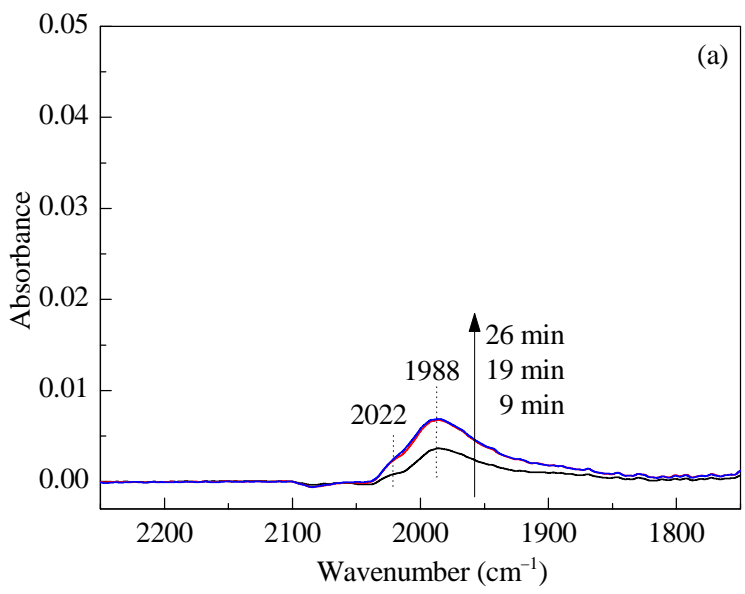

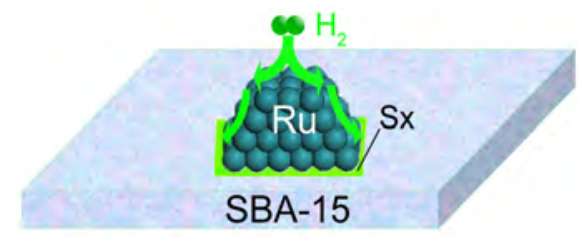

Scheme 1. Hydrogen spillover to active sites on periphery of Ru on SBA-15 in $\mathrm{H}_{2}$.

cess takes a longer time. The migration is also dependent on the $\mathrm{Ru}$ particle size; the smaller the $\mathrm{Ru}$ particle size is, the faster the migration of $\mathrm{H}$ atoms from $\mathrm{Ru}$ metal sites to $\mathrm{S}_{\mathrm{x}}$ is, as shown in Figs. 3 and 5.

The reactivities of these $\mathrm{H}$ species were evaluated using H-D exchange experiments. When $\mathrm{D}_{2}$ was introduced, the intensities of the hydroxyl bands at 3740 and $3660 \mathrm{~cm}^{-1}$ decreased, whereas the intensities of the deuteroxyl bands at 2760 and $2630 \mathrm{~cm}^{-1}$ increased, as shown in Fig. 6(a). Some of the hydroxyl groups corresponding to the band at $3660 \mathrm{~cm}^{-1}$ remained even after a few hours in $\mathrm{D}_{2}$. No changes in the bands at 2100-1800 $\mathrm{cm}^{-1}$ were observed. After flushing with a He flow for more than $1 \mathrm{~h}$, the adsorbed deuterium had been completely swept away, as in the case of adsorbed hydrogen in He. We then introduced $\mathrm{D}_{2}$ again to investigate the nature of the bands in the range 2100-1800 $\mathrm{cm}^{-1}$. As shown in Fig. 6(b), a band centered at $1987 \mathrm{~cm}^{-1}$ was formed in $\mathrm{D}_{2}$ but it was red shifted relative to the band at $1994 \mathrm{~cm}^{-1}$ in Fig. 5(b), and of much lower intensity than that in $\mathrm{H}_{2}$; the former change can be ascribed

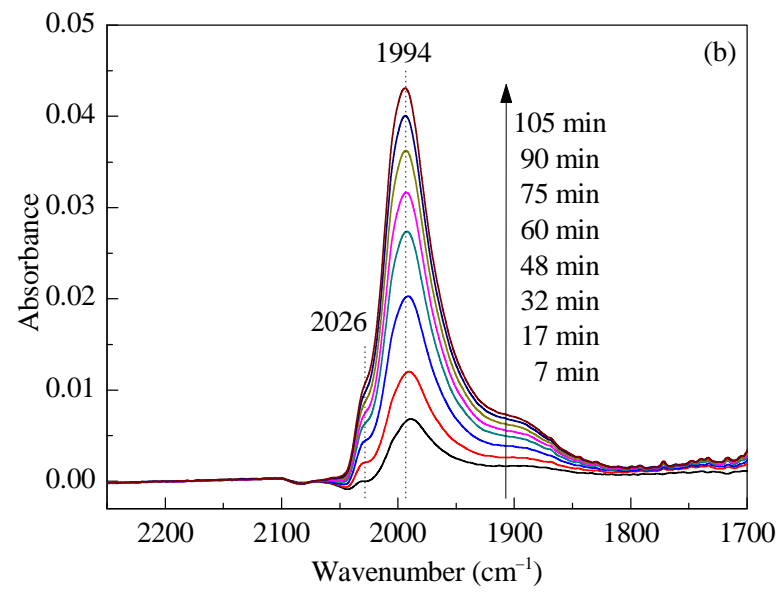

Fig. 5. Evolution of in situ FTIR spectra of reduced catalysts in $\mathrm{H}_{2}$ at $110{ }^{\circ} \mathrm{C}$. (a) Ru/SBA-15 (1\%); (b) Ru/SBA-15 (10\%). 

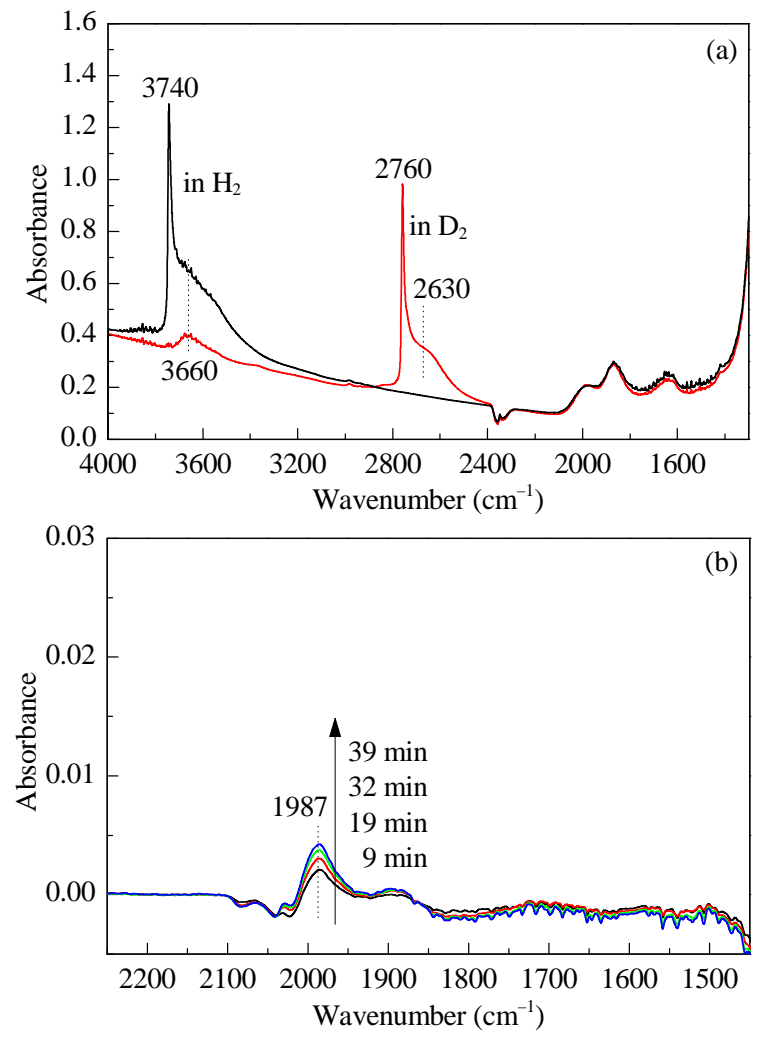

Fig. 6. In situ FTIR spectra of Ru/SBA-15 (10\%) during H-D exchange (a) and on exposure to $\mathrm{D}_{2}$ at $110{ }^{\circ} \mathrm{C}$ after complete removal of any adsorbed $\mathrm{H}$ species (b).

to the deuterium isotope effect [22]. No replacement of $\mathrm{H}$ species by D species occurred during H-D exchange (Fig. 6(a)), therefore the much weaker band for $\mathrm{D}$ species cannot be attributed to the deuterium isotope effect alone. It mainly arises because $\mathrm{D}$ species are less stable than $\mathrm{H}$ species.

Based on the above analysis, we propose a possible structure in which an $\mathrm{H}$ atom is coordinated to both $\mathrm{Ru}$ and $\mathrm{Si}$, as shown in Scheme 2. The formation of this structure is probably the intermediate step in the hydrogen spillover process. The red shift in the Si-H stretching band [23] from 2100 to 1996 $\mathrm{cm}^{-1}$ is probably caused by the presence of $\mathrm{Ru}-\mathrm{H}$ bonds from which electrons can be transferred to $\mathrm{Si}-\mathrm{H}$ species. This electron transfer is responsible for the higher reactivity of $\mathrm{Ru}-\mathrm{H}-\mathrm{Si}$ species compared with those of isolated $\mathrm{Si}-\mathrm{H}$ species reported in the literature [24-26]. It should be noted that hydrogenation

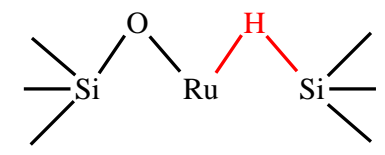

Scheme 2. Proposed structure of active sites on Ru/SBA-15.

may also take place on the Ru metal particle surfaces, but these active sites are more important when high selectivity toward targeted products is desired, especially when multi-bond hydrogenation is required [27].

\section{Conclusions}

In situ FTIR spectroscopy showed the presence of special adsorbed $\mathrm{H}$ species on reduced $\mathrm{Ru} / \mathrm{SBA}-15$ catalysts but not on $\mathrm{Pd} / \mathrm{SBA}-15, \mathrm{Ru} / \mathrm{Al}_{2} \mathrm{O}_{3}$, or SBA-15. These $\mathrm{H}$ species were differentiated from adsorbed $\mathrm{CO}$ species and were reproducible in $\mathrm{H}_{2}$. The formation rate of these $\mathrm{H}$ species depended on the $\mathrm{Ru}$ metal particle size, with small $\mathrm{Ru}$ particles giving faster formation of these $\mathrm{H}$ species. The amount of these $\mathrm{H}$ species was proportional to the Ru interfacial circumference, indicating that these species reside along the $\mathrm{Ru}-\mathrm{SiO}_{2}$ interface on the periphery of exposed $\mathrm{Ru}$ particles. H-D exchange experiments suggested that these $\mathrm{H}$ species were active in hydrogenation. A possible structure for these active sites was proposed.

\section{References}

[1] C. Newman, X. B. Zhou, B. Goundie, I. T. Ghampson, R. A. Pollock, Z. Ross, M. C. Wheeler, R. W. Meulenberg, R. N. Austin, B. G. Frederick, Appl. Catal. A, 2014, 477, 64-74.

[2] Y. F. Niu, H. Wang, X. L. Zhu, Z. Q. Song, X. N. Xie, X. Liu, J. Y. Han, Q. F. Ge, Microporous Mesoporous Mater., 2014, 198, 215-222.

[3] Y. M. Li, L. Ma, H. M. Liu, D. H. He, Chin. J. Catal., 2014, 35, 677-683.

[4] W. J. Li, L. M. Ye, J. Chen, X. P. Duan, H. Q. Lin, Y. Z. Yuan, Catal. Today, 2015, 251, 53-59.

[5] H. Y. Liang, G. Z. Chen, S. Desinan, R. Rosei, F. Rosei, D. L. Ma, Int. J. Hydrogen Energy, 2012, 37, 17921-17927.

[6] S. Akbayrak, S. Tanyıldızı, İ. Morkan, S. Özkar, Int. J. Hydrogen Energy, 2014, 39, 9628-9637.

[7] Q. L. Yao, Z. H. Lu, K. K. Yang, X. S. Chen, M. H. Zhu, Sci. Rep., 2015, 5, 15186-15196.

[8] D. O. Uner, M. Pruski, T. S. King, J. Catal., 1995, 156, 60-64.

[9] H. F. Xiong, Y. H. Zhang, K. Liew, J. L. Li, Fuel Process. Technol,, 2009, 90, 237-246.

\section{Graphical Abstract}

Chin. J. Catal., 2017, 38: 1597-1602 doi: 10.1016/S1872-2067(16)62571-8

Identification of active sites for hydrogenation over Ru/SBA-15 using in situ Fourier-transform infrared spectroscopy

Hangjia Shen, Xianyuan Wu, Dahao Jiang, Xiaonian Li, Jun Ni* Zhejiang University of Technology

The active sites for hydrogenation over Ru/SBA-15 catalysts were identified using in situ FTIR spectroscopy. The formation of these active sites is probably an intermediate step in hydrogen spillover.

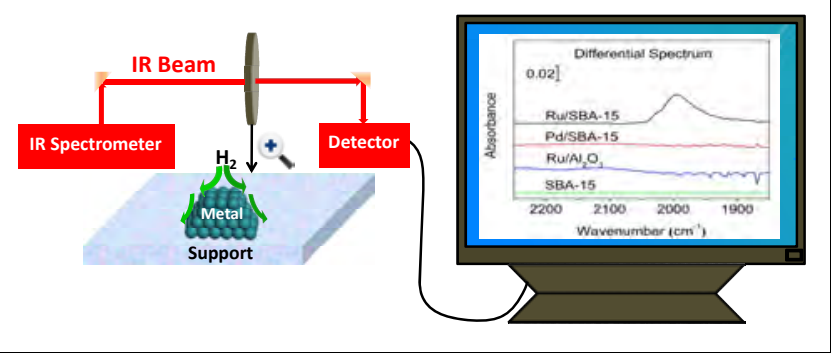


[10] B. R. Cuenya, Acc. Chem. Res., 2012, 46, 1682-1691.

[11] A. Vimont, F. Thibault-Starzyk, M. Daturi, Chem. Soc. Rev., 2010, 39, 4928-4950.

[12] J. M. Basset, G. Dalmai-Imelik, M. Primet, R. Mutin, J. Catal., 1975, 37, 22-36.

[13] A. Corma, L. T. Nemeth, M. Renz, S. Valencia, Nature, 2001, 412, 423-425

[14] D. Y. Zhao, J. L. Feng, Q. S. Huo, N. Melosh, G. H. Frederickson, B. F. Chmelka, G. D. Stucky, Science, 1998, 279, 548-552.

[15] M. Imperor-Clerc, D. Bazin, M. D. Appay, P. Beaunier, A. Davidson, Chem. Mater., 2004, 16, 1813-1821.

[16] J. L. Liu, L. J. Zhu, Y. Pei, J. H. Zhuang, H. Li, H. X. Li, M. H. Qiao, K. N. Fan, Appl. Catal. A, 2009, 353, 282-287.

[17] H. Ishikawa, J. N. Kondo, K. Domen, J. Phys. Chem. B, 1999, 103, 3229-3234.
[18] Z. Pei, T. H. Fang, S. D. Worley, J. Phys. Chem., 1995, 99, 3663-3670.

[19] M. Kantcheva, S. Sayan, Catal. Lett., 1999, 60, 27-38.

[20] G. H. Yokomizo, C. Louis, A. T. Bell, J. Catal., 1989, 120, 1-14.

[21] K. Hadjiivanov, J. C. Lavalley, J. Lamotte, F. Mauge, J. Saint-Just, M. Che, J. Catal., 1998, 176, 415-425.

[22] C. K. Costello, J. H. Yang, H. Y. Law, Y. Wang, J. N. Lin, L. D. Marks, M. C. Kung, H. H. Kung, Appl. Catal. A, 2003, 243, 15-24.

[23] C. Copéret, D. P. Estes, K. Larmier, K. Searles, Chem. Rev., 2016, 116, 8463-8505.

[24] C. Morterra, M. J. D. Low, J. Phys. Chem., 1969, 73, 321-326.

[25] C. Morterra, M. J. D. Low, J. Phys. Chem., 1969, 73, 327-333.

[26] A. Van Meerbeek, A. Jelli, J. J. Fripiat, J. Catal., 1977, 46, 320-325.

[27] G. Kennedy, G. Melaet, H. L. Han, W. T. Ralston, G. A. Somorjai, ACS Catal., 2016, 6, 7140-7147.

\title{
利用原位红外光谱确证Ru/SBA-15的加氢活性位点
}

\author{
沈行加, 吴先元, 江大好, 李小年, 倪 珺 ${ }^{*}$ \\ 浙江工业大学工业催化研究所, 浙江杭州 310014
}

摘要: Ru/SBA-15催化剂具有高的氢气活化能力, 因此被广泛应用在加氢和氢解反应中. 一般认为Ru/SBA-15催化剂的高活 性与金属Ru的高分散有关, 然而有研究发现在氧化硅载体上还存在溢流的氢, 这部分溢流氢也很可能参与加氢和氢解反 应. 这就产生了两个关键性的问题: (1) Ru/SBA-15的催化加氢活性中心是什么, 是金属Ru还是载体SBA-15; (2)在金属Ru 上解离的 $\mathrm{H}$ 是如何迁移到载体上的. 因此, 加氢活性位点及其形成机理的确认对理解 $\mathrm{Ru} / \mathrm{SBA}-15$ 催化剂的高活性至关重要.

原位红外光谱可从分子层面研究在工作状态的催化剂表面活性位点的状态, 进而推测可能的反应机理. 通过与催化剂 $\mathrm{Pd} / \mathrm{SBA}-15, \mathrm{Ru} / \mathrm{Al}_{2} \mathrm{O}_{3}$ 和 SBA-15比较发现, 在氢气氛围中 $\mathrm{Ru} / \mathrm{SBA}-15$ 催化剂的原位红外谱图中存在一个独特的位于1996 $\mathrm{cm}^{-1}$ 的峰. 由于在 $\mathrm{Pd} / \mathrm{SBA}-15, \mathrm{Ru} / \mathrm{Al}_{2} \mathrm{O}_{3}$ 和SBA-15上都不存在这个峰, 因此该峰的形成是金属 $\mathrm{Ru}$ 和SBA-15相互作用的结果. 此外, Si-O键在位于 $1866 \mathrm{~cm}^{-1}$ 的合频峰不随氢气氛围变化而变化, 因此可排除这个峰属于 $\mathrm{Si}-\mathrm{O}$ 键振动的倍频峰. 为了排除 该峰的产生是由于CO的吸附, 我们采用脉冲引入CO的方法, 发现在低的CO覆盖率下, 红外谱图中位于 $2068 \mathrm{~cm}^{-1}$ 处出现了 一个 $\mathrm{CO}$ 在 $\mathrm{Ru}^{\delta+}$ 上的线性吸附峰. 随着 $\mathrm{CO}$ 覆盖率增加, 该峰逐渐蓝移至 $2075 \mathrm{~cm}^{-1}$, 同时位于 $2132 \mathrm{~cm}^{-1}$ 处的峰强度增强了, 这 两个峰都归属于 $\mathrm{Ru}^{n+}(\mathrm{CO})_{x}$ 物种的振动峰. 这些CO的化学吸附强度都很高, 即使在 $\mathrm{He}$ 气中吹扫 $1 \mathrm{~h}$ 后仍然存在, 而 $1996 \mathrm{~cm}^{-1}$ 峰的形成是可逆的. 此外, 低CO覆盖率下生成的吸附峰 $\left(2068 \mathrm{~cm}^{-1}\right)$ 的强度低于 $1996 \mathrm{~cm}^{-1}$ 峰的强度, 因此可以排除1996 $\mathrm{cm}^{-1}$ 峰属于CO吸附峰的可能. 既然 $1996 \mathrm{~cm}^{-1}$ 峰的形成是可逆的, 将这个峰归属于载体上氢的可能性也可排除, 因为形成载 体上氢的过程是不可逆的. 另外, 形成 $1996 \mathrm{~cm}^{-1}$ 峰的速率还证明了这个峰不属于金属 $\mathrm{Ru}$ 上吸附的氢, 因为金属 $\mathrm{Ru}$ 上氢的 吸附是很快的. 通过以上分析, 我们推断 $1996 \mathrm{~cm}^{-1}$ 峰应该指认为在Ru和SBA-15界面处位点的红外峰.

为了证明这一点, 我们制备了不同Ru负载量的Ru/SBA-15催化剂, 发现这个界面处位点峰的峰面积与金属Ru颗粒在载 体上形成交界面的周长成正比, 而峰达到稳态所需时间与 $\mathrm{Ru}$ 颗粒大小成反比. 这说明 $\mathrm{H}_{2}$ 在金属 $\mathrm{Ru}$ 上发生解离吸附后迁移 到 $\mathrm{Ru}$ 和SBA-15界面处, 形成了 $\mathrm{Ru}-\mathrm{H}-\mathrm{Si}$ 物种. 当金属 $\mathrm{Ru}$ 的颗粒比较小时, 与载体形成交界面的周长小, $\mathrm{Ru}-\mathrm{H}-\mathrm{Si}$ 物种的数 量少, 体现在红外谱图上峰的峰面积小, 但解离的氢迁移到该界面所需时间变短了. 当金属 Ru的颗粒比较大时, 与载体形 成交界面的周长大, $\mathrm{Ru}-\mathrm{H}-\mathrm{Si}$ 物种的数量多, $1996 \mathrm{~cm}^{-1}$ 峰的峰面积大, 但解离氢的迁移慢了. 此外, H-D交换实验还证明这 个界面处的位点具有加氢活性. 与文献报道的孤立 $\mathrm{Si}-\mathrm{H}$ 物种的红外峰位置比较发现, Ru-H-Si物种具有明显的峰红移现 象, 说明该物种中的 $\mathrm{Si}-\mathrm{H}$ 键活性很高, 这可能是由于金属 Ru将电子转移至 $\mathrm{Si}-\mathrm{H}$ 键的结果. 总之, 以上结果清晰地表明这个 $1996 \mathrm{~cm}^{-1}$ 峰归属为结构是 Ru-H-Si的活性位点.

关键词: Ru/SBA-15催化剂; 原位红外光谱; 加氢反应; 活性位点; 氢溢流

收稿日期: 2016-11-25. 接受日期: 2016-12-30. 出版日期: 2017-09-05.

*通讯联系人. 电话/传真: (0571)88320092; 电子信箱: Junni@zjut.edu.cn

基金来源：国家自然科学基金(21303163); 浙江省自然科学基金(LY13B030006, LY17B060006); 浙江省“钱江人才计划” (QJD1302011); 浙江省教育厅科研项目(Y201328681).

本文的英文电子版由Elsevier出版社在ScienceDirect上出版(http://www.sciencedirect.com/science/journal/18722067). 